Vol. 7(1998): 149-160.

\title{
Climatic conditions for crop production in Nordic countries
}

\author{
Arne Oddvar Skjelvåg \\ Department of Horticulture and Crop Sciences, Agricultural University of Norway, N-1432 As, \\ Norway,e-mail: arne.skjelvag@iph.nlh.no
}

\begin{abstract}
Climate is today a more determinant factor for yield level than it was in the past, when soil fertility was more important. The regional variation in radiation during the growing season in Nordic countries is less than that in temperature conditions. A combined plant growth-related index of these climatic factors accumulated during the growing season decreased from an annual value of 106 at $56^{\circ} \mathrm{N}$ (Ødum, East Jutland) to about 90,60 and 44 at $60^{\circ} \mathrm{N}, 67^{\circ} \mathrm{N}$ and $70^{\circ} \mathrm{N}$, respectively. The difference between coastal areas in Norway and the Finnish interior was either negligible or about $10 \%$ in disfavour of the coast at $67^{\circ} \mathrm{N}$. When the moisture conditions of an imaginary pasture crop on a sandy soil were taken into account, the combined accumulated growth index of radiation, temperature and soil moisture was 71 at Ødum. On the Norwegian coast, the values were 72,49 and 37, whilst in Finland, up to northeastern Norway, they were 56,43 and 35 at $60^{\circ} \mathrm{N}, 67^{\circ} \mathrm{N}$ and $70^{\circ} \mathrm{N}$, respectively. Plant production potential may be directly related to the accumulated growth index.
\end{abstract}

Key words: daylength, radiation, soil moisture, temperature

\section{Introduction}

A crop production system consists, on the one hand, of environmental components: soil, climate, pests and management practices, and on the other, of the plant material. Either of the factors - environment or plant genetic potential can be the more limiting with respect to yield level (Geisler 1980). The main components are strongly affected by management and breeding.

The natural resource base of the environmental component consists of soil and climate. Of these two, the climatic component has assumed an increasingly determinant role in yield formation in recent decades along with the improvement in management practices. Before 1940, the average grain yields in three Norwegian regions ranged from 2100 to $2300 \mathrm{~kg} / \mathrm{ha}$, being lowest in the southern Oslofjord area $\left(59-60^{\circ} \mathrm{N}\right)$, highest in the Mjøsa region $\left(61^{\circ} \mathrm{N}\right)$, and intermediate in Central Norway $\left(63-64^{\circ} \mathrm{N}\right)$. In the $1980 \mathrm{~s}$, yields generally had doubled, being highest in the south, intermediate in the Mjøsa region and lowest in Central Norway (Strand 1989). The Oslofjord region consists of Precambrian or Permian 
bedrock, whilst the soils of the main agricultural areas of the other two regions derive from Cambrian and Silurian rocks. Today grain yield is controlled by climatic conditions, whereas formerly it depended more on soil fertility.

The interaction between soil and climate is nevertheless still crucial. Pest attacks are greatly influenced by climatic factors and, to be timely and successful, even modern field operations need favourable weather conditions. A physical geographical regional division based on natural vegetation integrates climatic and edaphic factors (e.g. NU B 1977). The applicability of this division for agronomic purposes is, however, poor because of the high degree of manipulation in agricultural ecosystems. Comprehensive mapping of land capability based on both soil and climate is still lacking in the Nordic countries. Thus, the methods used for characterising the natural resources for crop production described here are based mainly on climatic criteria.

The three main climatic factors determining crop growth and development are the energy flow by radiation, temperature, and the soil moisture supply as related to weather, soil and plant parameters. Photoperiod may also be a critical factor, for perennial crops in particular.

\section{Radiation}

The variation in radiation climate throughout the Nordic countries is considerable due to their great geographic extent from south to north and to regional differences in cloud cover, although, at about the summer solstice, the daily radiation is more or less the same in southernmost and northernmost Norway. Reduced insolation in the north due to the lower elevation of the sun at that time is compensated by a longer photoperiod. From April to September the variation in total global radiation with latitude may be more than $20 \%$ of the average (Fig. 1). During the growing season defined by temperature limits, the differences are less prominent, because the

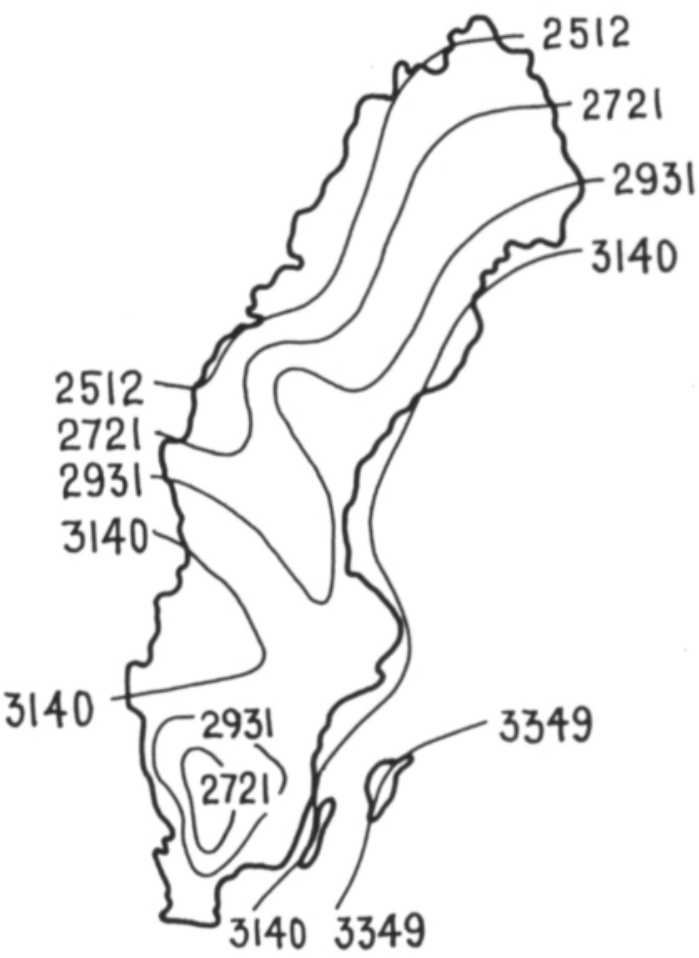

Fig. 1. Accumulated insolation, $\mathrm{MJm}^{-2}$, in Sweden from April to September during an unspecified number of years (Ångström et al. 1974).

season in the north is more strongly restricted to the period with the highest insolation. The variation from west to east may be of equal magnitude to that from south to north, as indicated by data on Sweden (Fig. 1). A similar variation is found in all the Nordic countries except Finland (SNP 1992). Within a region, too, the monthly sums of global radiation may differ between sites by as much as $20 \%$, even over short distances (Gjessing 1969). When the aspect and slope of the ground are included, the monthly means of radiation intensity may differ by up to $\pm 15 \%$ in the Sognefjord area of Norway (Gjessing 1969).

Although the displacement in spectral distribution from shorter to longer wavelengths is greater in the north than in southerly locations (Kvifte et al. 1983), the spectral distribution of photosynthetic active radiation and the near infrared part of the spectrum can probably be omit- 


\section{AGRICULTURAL AND FOOD SCIENCE IN FINLAND}

Vol. 7 (1998): 149-160.

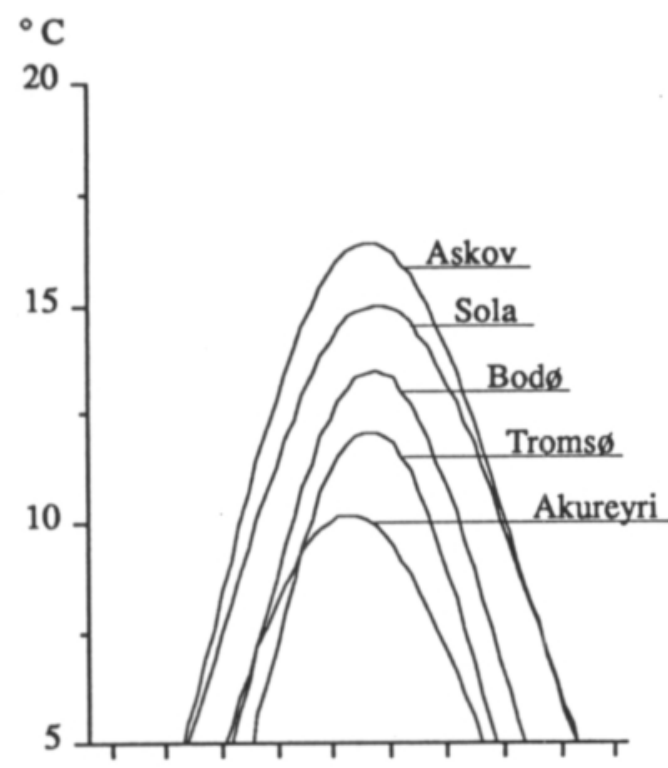

$\begin{array}{lllllllll}M & \text { A } & \text { M } & \text { J } & \text { J } & \text { A } & \text { S } & \text { O } & \text { N }\end{array}$

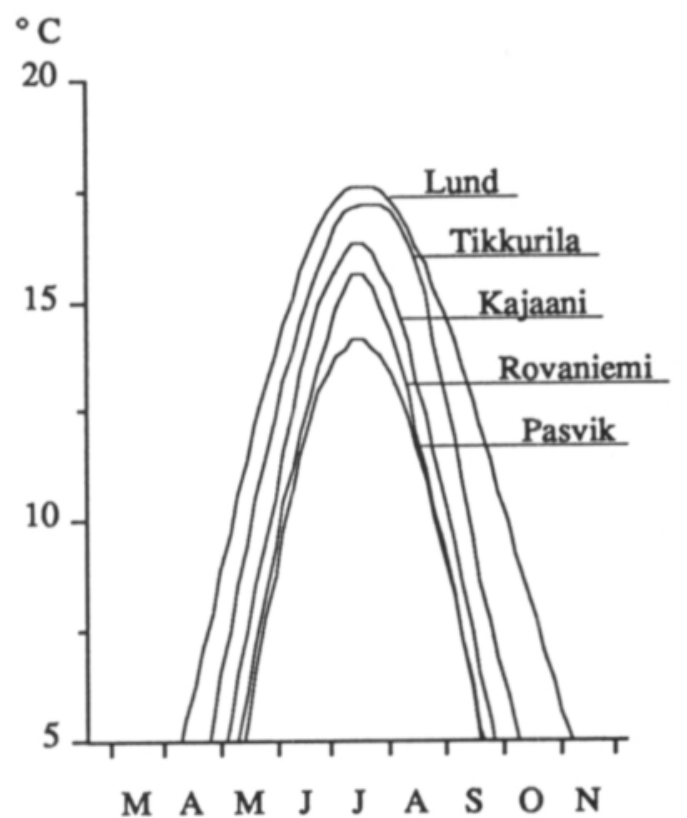

$\begin{array}{lllllllll}\text { M } & \text { A } & \text { M } & \text { J } & \text { J } & \text { A } & \text { S } & \text { O } & \text { N }\end{array}$

Fig. 2. Normal air temperature from 1931 to 1960 as 5-day means at certain sites in the Nordic countries. Norwegian data after Bruun (1967); Danish, Icelandic and Swedish data calculated by Fourier series from monthly means (J.E. Olesen, pers. comm.), and Finnish data from monthly means (R. Solantie, pers. comm.), cf. SNP (1992).

ted from agroclimatic mapping without risks of a serious error.

\section{Temperature}

The normal air temperature during the high summer peak ranges from below $10^{\circ} \mathrm{C}$ to over $17^{\circ} \mathrm{C}$ in areas with agricultural production in the Nordic countries. Between a coastal area and the interior at the same latitude and altitude summer temperatures may differ by more than $5^{\circ} \mathrm{C}$. Temperature level is frequently used to determine the start and end of the growing season. When the passage of $5^{\circ} \mathrm{C}$ diurnal mean temperature is used as the criterion in both spring and autumn, the duration of the growing season varies from 220 to 120 days, the latter referring to areas with agriculture in northernmost and mountainous regions.
The western and eastern transects from south to north in Figure 2 indicate higher peaks in the east, and a slower rise and fall in temperature curves, and a more pronounced north-south gradient in the west. Curves based on 30-year standard normals are regular in shape, and so the average temperature conditions of the growing season can be characterised by selecting two monthly means only (Fig. 3). A higher April temperature indicates an early spring. In Norway, the April temperature is closely correlated with the time of the thaw, and distribution from north to south is seen along the ordinate. July temperature indicates continentality, and distribution from west to east is shown along the abscissa.

Figure 3 shows that Finland, all the way from south to north, is on the continental side of the scatter diagram. Denmark has the highest temperatures in both spring and summer. Iceland represents an extreme maritime climate, but an equivalent is found in the Lofoten region of northern Norway. The two countries on the Scan- 


\section{AGRICULTURAL AND FOOD SCIENCE IN FINLAND}

\section{Seminar in honour of the 100th anniversary of MTT}

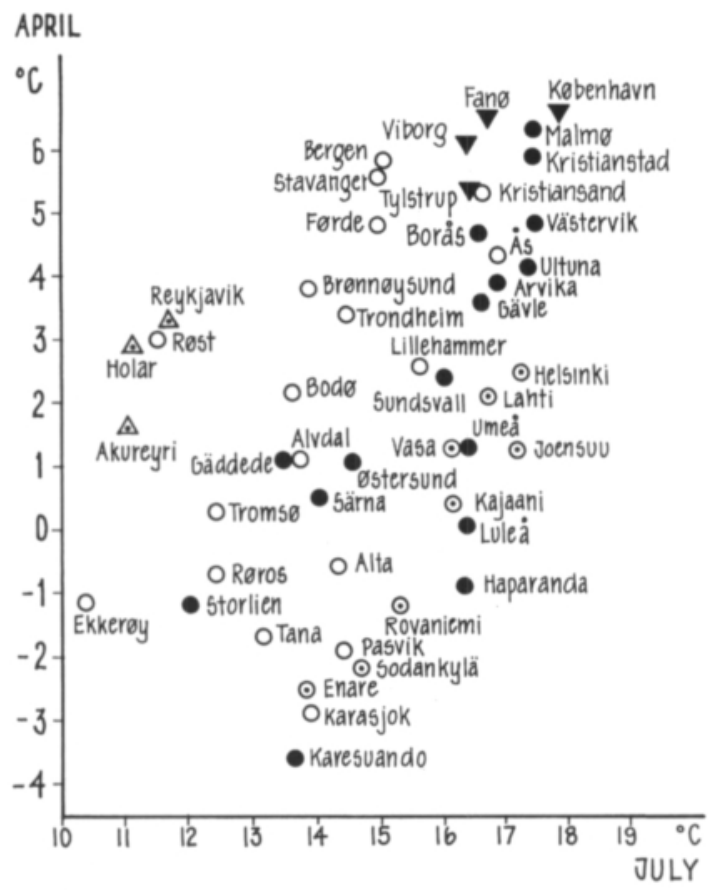

Fig. 3. Nordic sites distributed according to monthly mean temperatures of April and July 1931-1960. $\boldsymbol{\nabla}$ Denmark, $\odot$ Finland, $\triangle$ Iceland, O Norway, - Sweden. (Several public sources of the Nordic meteorological institutes).

dinavian peninsula, Norway and Sweden, partly overlap, northern Sweden partly with Finland, and southern Sweden with Denmark. Thermally, mountainous sites in southern Norway and northern Sweden resemble coastal locations in northern Norway during spring and summer. The larger agricultural areas of the Nordic countries have the climatically most favourable conditions, i.e. higher April and July temperatures.

The temperature sum is the climatic index most widely used to characterise the temperature climate for agricultural production. Its advantage is that it combines temperature level and duration of the growing period into a single term. Figure 4 shows that the temperature sum of Finland with a $5^{\circ} \mathrm{C}$ base ranges from 600 to 1300 day degrees. In Denmark, it ranges from ca. 1350 to 1700 day degrees from 1 May to 31 October (Mikkelsen and Olesen 1984). Along a western

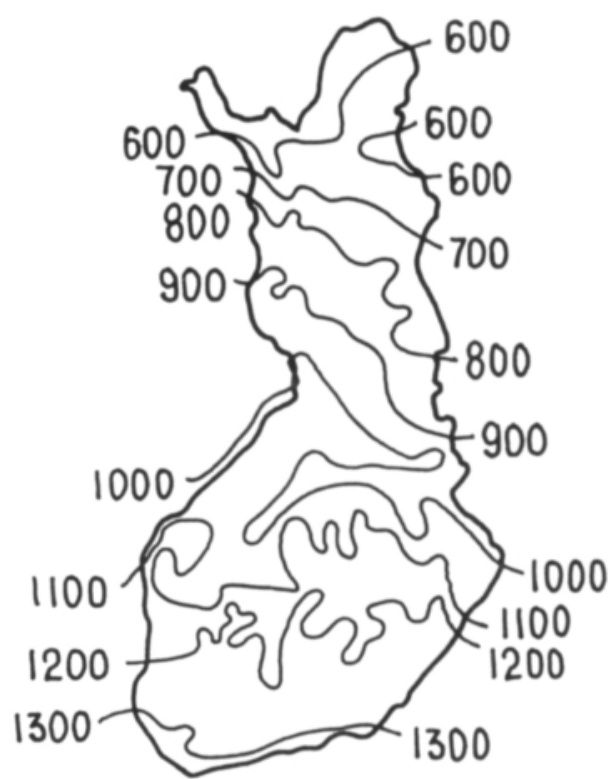

Fig. 4. Annual temperature sum in Finland with $5^{\circ} \mathrm{C}$ as base temperature and recordings from 1931 to 1960 (Solantie 1976).

transect the temperature sum above the same base temperature in Norway ranges from about 550 to 1550 degree days for crop production areas (B. Aune, The Norwegian Meteorological Institute, pers. comm.).

Growing conditions have been characterised by means of the temperature sum in various ways in the Nordic countries, and a comprehensive comparison is not possible (SNP 1992). The temperature sum, which represents a general characterisation omitting other important factors such as radiation, soil moisture regime and specific requirements of individual crops, is a linear approximation of the relationship between temperature and the rate of phenological development. It is therefore a useful index of assessing the thermal conditions needed for a seed crop to reach maturity, and as such is widely used (e.g. Strand 1964). However, such a simple index may put typical coastal and inland areas in Norway into the same climatic zone for choice of cereal cultivars, even though the climatic conditions for grain production are quite different. Further- 
Vol. 7 (1998): 149-160.

more, the assumption of a linear relationship between temperature and rate of phenological development does not always hold, and the base temperature certainly varies with the phenological phase (Skjelvåg 1981b).

An alternative approach can be illustrated by analysing climatic conditions for the phenological development of annual ryegrass (Lolium multiflorum L. var. westerwoldicum) in AustAgder county, Norway. There, the range of temperature from sea level to about $1000 \mathrm{~m}$ a.s.l. is similar to that from south to north in the whole country. Using daily weather records and starting with the first day of snowless ground (Skjelvåg 1987), we were able to calculate the earliest sowing day from weather and soil parameters (Skjelvåg 1986b) and the rate of phenological development as a function of diurnal mean temperature (Skjelvåg 1986a), and to define the end of the growing season by the passage of a $6^{\circ} \mathrm{C}$ diurnal mean temperature for a 7 day period. Series of daily weather records over decades were applied to assess annual variation (Skjelvåg 1986c). On a clay loam at about sea level the number of summers in a 27 -year period permitting 4, 3 or only 2 harvests were 4,17 and 8, respectively. At about $200 \mathrm{~m}$ a.s.1., 2 or 3 harvests per year were equally frequent, whereas no more than one harvest per year was ever possible at $920 \mathrm{~m}$ a.s.l. For a seed crop, a risk analysis of harvesting conditions should be included. Decisions under uncertainty are characteristic of crop production. More analyses of climatic risks of various types should therefore be carried out (e.g. Mukula and Rantanen 1987, Rantanen and Solantie 1987).

\section{Daylength}

Photoperiod varies regularly with season and latitude. From an equal duration of day and night at the spring equinox, a maximum daylength of about $17 \mathrm{~h}$ is reached in southern Denmark and of $24 \mathrm{~h}$ at the Arctic Circle and northwards. Dur-

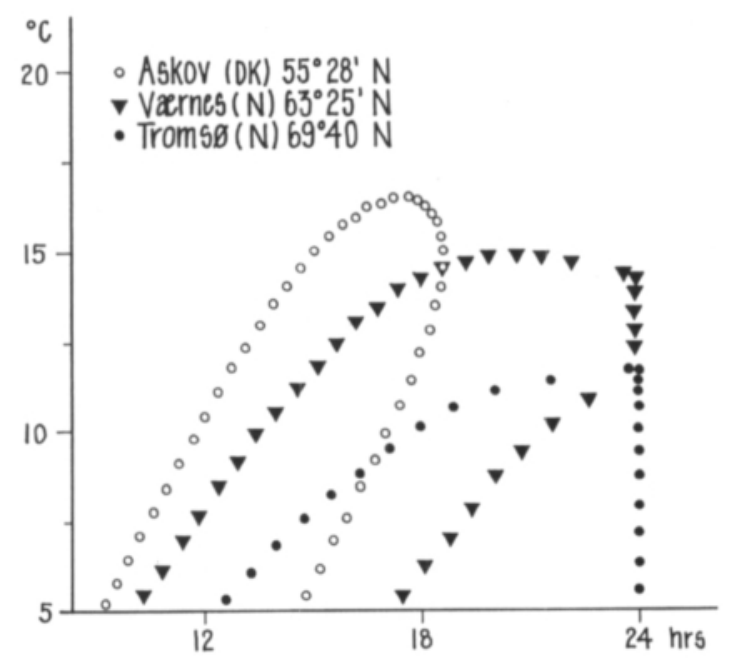

Fig. 5. Photothermogram with corresponding 5-day air temperature averages (1931-1960 normals) and photoperiod including civil twilight to $-4^{\circ}$ at one location in Denmark, and at two locations in Norway. Each point represents a 5day period, the right-hand branches of the curves describe the period from the passage of the $5^{\circ} \mathrm{C}$ diurnal mean in spring to the summer solstice, and the left-hand ones the remaining part of summer and autumn.

ing the growing season, daylength varies from 14 to $24 \mathrm{~h}$ at the start and from 9 to $12 \mathrm{~h}$ at the end of the period (Fig. 5).

An increase in daylength enhances the rate of phenological development of long-day plants. In old Norwegian cultivars of spring cereals, the degree days requirement from sowing to yellow ripeness was reduced by $3-7 \%$ when the cereals were grown at $63^{\circ} \mathrm{N}$ rather than $60^{\circ} \mathrm{N}$ (Eikeland 1936). Since photoperiod affects the rate of development only before heading (Bleken and Skjelvåg 1986), the relative reduction in day degrees must have been about twice this figure during that phase. Such a reduction in thermal requirement contributes to successful cereal production in cool areas of the north.

From phytotron experiments we know that a long photoperiod stimulates the dry matter production of grass seedlings of Nordic ecotypes (Heide et al. 1985). This stimulation compensates for a reduction in temperature of several degrees centigrade (Heide 1985). However, we 


\section{Seminar in honour of the 100th anniversary of MTT}

still lack proof as to whether this effect manifests itself in a crop stand (Hay 1990).

Growth cessation of perennial crops is strongly affected by photoperiod. We can assume that elongation growth has to stop early enough to ensure the accumulation of reserve carbohydrates before photosynthesis becomes negligible. Clearly an ecotype adapted to northern conditions must stop growing at a longer photoperiod than one of southern origin (Fig. 5). This phenomenon is recognised in grassland production. Foss (1968) grew 14 Nordic timothy ecotypes originating from approximately $59^{\circ} \mathrm{N}$ to $69^{\circ} \mathrm{N}$ in the same field at $63^{\circ} \mathrm{N}$. Regrowth during the period 14 July to 30 September decreased linearly with latitude of origin, $r=-0.91$. This response to photoperiod is favourably exploited in ensuring winter hardiness by using northern grass cultivars at high-altitude areas farther south (Baadshaug 1974).

Most perennial grasses of northern origin have a dual requirement for induction to flowering (Heide 1994). Primary induction is brought about by low temperature and/or short days, and secondary induction by long days. Seed yields have been poor for North Norwegian ecotypes of smooth meadow grass (Poa pratensis L.) transferred to Denmark for seed production, and have even failed when transferred to the Netherlands and Canada (Heide 1980). Arctic ecotypes attain primary induction at longer days than southern ones. Thus, they will reach an early and advanced stage of flower development when grown in the long autumns of southern latitudes, making the primorida vulnerable to insect and winter damage, particularly in years and regions with unstable winter weather and recurrent freezing and thawing.

\section{Water supply}

Within the driest areas of the Nordic countries the mean annual precipitation is only $200-250 \mathrm{~mm}$, but in the wettest areas it exceeds $4000 \mathrm{~mm} / \mathrm{yr}$.
Large areas in the northeast get less than $500 \mathrm{~mm} / \mathrm{yr}$. More than $1000 \mathrm{~mm} / \mathrm{yr}$ falls in southernmost Norway, to the west of the mountain range up to $69^{\circ} \mathrm{N}$, and in the south of Iceland (Sømme 1968). Annual evaporation is estimated to vary from about $200 \mathrm{~mm}$ in the north to $600 \mathrm{~mm}$ in the south of the Nordic countries (Johannessen 1970, Einarsson 1972). However, evaporation is most intense during the growing season, and a precipitation deficit is common in the larger agricultural areas.

The main factors determining the natural water supply to plants are the amount and distribution of rainfall, soil moisture capacity, evaporation and the development of plant organs above and below the ground. Thus, soil and plant development assume as great importance as climatic variables for determining water balance, and this creates problems in defining a geographical index based on soil moisture characteristics.

Simplified indices such as the potential precipitation deficit (PPD) have therefore been established. PPD is defined as the difference between potential evapotranspiration and rainfall during a specified period of time, disregarding soil moisture capacity and plant development. Utaaker (1979) calculated PPD for May to August 1966 for a $160-\mathrm{km}$ transect along the Sognefjord and found a variation from a deficit of 150 $\mathrm{mm}$ to a surplus of $250 \mathrm{~mm}$. Probably the whole agricultural area of the Nordic countries falls within this range. In Sweden, from June to August 1951-1980, PPD was estimated to range from more than $100 \mathrm{~mm}$ in the southeast to a surplus of 100 to $150 \mathrm{~mm}$ locally in the southwest. The larger agricultural areas had a deficit (Eriksson 1986).

More specific estimates have been made in Denmark and Finland. Actual evaporation from grassland in Finland was estimated to range from 150 to $350 \mathrm{~mm} / \mathrm{yr}$ (Fig. 6). Based on weather records for 1931-1960 and for the period from thaw to the end of July, a deficit of $120 \mathrm{~mm}$ was estimated for southwestern Finland, and a surplus of about $40 \mathrm{~mm}$ for the northernmost part of the country. In Denmark, detailed soil map information has been combined with weather and 
Vol. 7 (1998): 149-160.

plant data to estimate irrigation needs. For spring barley the average need varied from less than 40 to up to $80 \mathrm{~mm}$ per season (Madsen et al. 1987).

\section{Other elements}

Several other factors besides the four climatic ones discussed above also influence conditions for crop production; one of these is overwintering of perennial and biennial crops. It has been estimated that annual losses due to winter damage to grassland and biennial crops in the Nordic countries total NOK 900 million (Vinterherdighet 1988). The climatic influence on overwintering starts in the preceding summer and autumn with growth cessation, accumulation of reserves and hardening. It continues during the winter with dehardening, rehardening, the impact of frost, the creation of conditions conducive to water and ice damage, attacks by wintering fungi, and a general exhaustion of reserves with time. The situation varies markedly from region to region and is counteracted by both improved management practices and breeding for winter hardiness. A brief description of the predominant types of winter damage in various parts of the Nordic countries is given elsewhere (SNP 1992). Internationally, attempts have been made to quantify relationships between climate and pests and diseases (e.g. Mischenko 1984); Nordic attempts in this field seem, however, to be lacking.

Various operations in crop production are best carried out when it is not raining. The cost due to suboptimal timing of such operations is a function of weather, crop and technical equipment. Danish agrometeorologists have calculated the number of possible harvesting hours for spring barley in 1953-1980 for a range of required moisture contents of the grain (Olesen and Mikkelsen 1985a, 1985b). Agroclimatic mapping of this type emphasises the need for a high resolution level of weather observations; these are, however, still very scarce (SNP 1992).
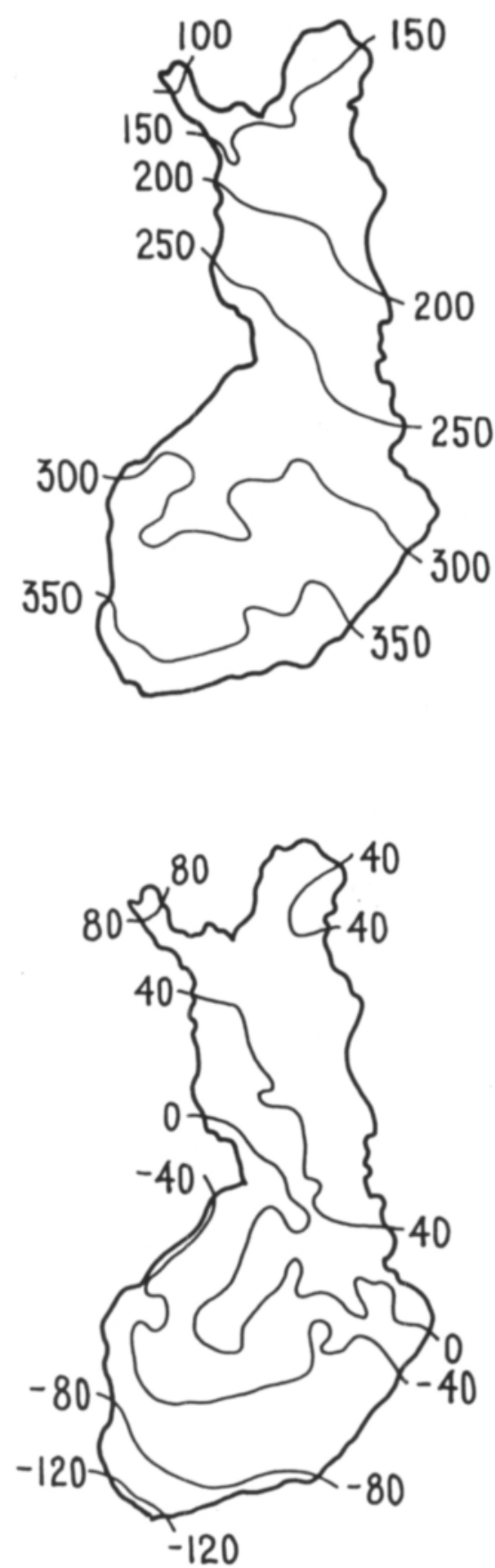

Fig. 6. Upper: Actual evaporation from grassland, $\mathrm{mm} / \mathrm{yr}$ (after Solantie 1975, 1976). Lower: Difference between precipitation and actual evaporation of grassland from thaw to the end of July, mm (after Solantie 1987). Both: Based on weather records 1931-1960. 


\section{AGRICULTURAL AND FOOD SCIENCE IN FINLAND}

\section{Seminar in honour of the 100th anniversary of MTT}

\section{Growth indices}

Characterisation of the climatic conditions for crop growth by means of a growth index combining radiation, temperature and soil moisture was proposed for Nordic conditions by Angus et al. (1980), and applied on a global scale by Hutchinson et al. (1992). A grassland model developed by a Swedish team has been used for some Nordic locations. The start and end of the growing season was set to the passage of a diurnal mean temperature of $5^{\circ} \mathrm{C}$ for a 7 -day period. Radiation and temperature indices were calculated according to Torssell and Kornher (1983), whilst a soil moisture index was estimated according to a model of Ritchie (1972) and modified by Skjelvåg (1981a). The root zone field capacity of plant available water was set to 90 $\mathrm{mm}$, which was assumed to be the available soil moisture content at the start of the growing season. The phase I soil evaporation of the Ritchie model was set to $4.0 \mathrm{~mm}$, and its $\alpha$-value, which determines maximum soil evaporation in phase II, to $3.5 \mathrm{~mm} / \mathrm{day}^{0.5}$, representing a sandy soil. The fraction of plant available soil moisture readily available for plants was set to $20 \%$. Leaf area index was set to 1.4 at growth start, allowed to increase to 2.0, and thereafter kept constant throughout the rest of the season. Long series of weather records were applied (Table 1). Potential evapotranspiration was estimated according to Penman (1956) for Norwegian stations and according to a modified Penman equation for Denmark (Mikkelsen and Olesen 1991). For Finnish stations, Class A pan evaporation was adjusted by a factor of 1.06 according to Heldal (1969).

The model estimates give indices of radiation related to plant growth (RI), temperature (TI) and soil moisture (SMI). These indices show curvilinear relationships between plant growth and radiation, temperature and availability of soil moisture to the crop, respectively. All the indices were computed on a day-by-day basis using annual series of daily weather recordings. They have a value of 0.0 when individual factors limit plant growth absolutely, and 1.0 when they are at their optimal levels. The combined growth index (GI) was defined as: GI = RI*TI*SMI. Soil moisture may be controlled by irrigation, but RI and TI cannot be controlled under field conditions. The combined effect of these two was defined as: RTI $=$ RI*TI. All derived means or sums presented in Tables 1 to 3 are based on the daily values of long term series.

Taking East Jutland (Ødum) as a reference site, the energy supply as characterised by RTI decreases northwards (Table 1). Along the coast of Norway it decreases northwards in all months, but only slightly from $67^{\circ} \mathrm{N}$ to $70^{\circ} \mathrm{N}$ in July. Along a northeastern transect from Denmark through Finland to Pasvik in Norway, RTI remains high in June and July up to higher latitudes than it does in the west. At the beginning and end of the growing season, there is less difference between western and eastern transects. The same difference between coastal and inland areas is seen by comparing locations at about the same latitude, and even in May at about $60^{\circ} \mathrm{N}$.

In July, RTI attains about three-quarters of its maximum value of 1.0 in Denmark, southern Finland and southeastern Norway, but it is reduced by one-third to about half of the maximum value in the far north (Table 1). Earlier and later in the season the reduction is greater due to the shorter growing season in the north. Thus, the figures show that energy and thermal constraints on crop production generally increase northwards and westwards. However, when we consider the total production potential as expressed by GI, soil moisture conditions modify the above picture considerably. The difference between GI and RTI (Table 2) shows that the soil moisture deficit reduces crop production potential more in the south than it does in the north, and more in the east than in the west (Table 2).

Ley yields in Sweden, simulated by the same grassland model, though with a different soil moisture routine, agreed well with independent field observations, both as averages and as standard deviations (Fagerberg 1991). Thus, GI may be an appropriate indicator of dry matter production potential. In the case of Denmark, with 
Vol. 7 (1998): 149-160.

Table 1. Long-term daily means of the combined radiation and temperature index (RTI) multiplied by 100 , at Nordic locations. Contributing indices only for days with diurnal mean temperature above $5^{\circ} \mathrm{C}$, after passing $5^{\circ} \mathrm{C}$ for a 7 -day period in spring and until passage of the same temperature in autumn.

\begin{tabular}{|c|c|c|c|c|c|c|c|c|c|c|c|}
\hline \multirow[b]{2}{*}{ Location } & \multirow[b]{2}{*}{${ }^{\circ} \mathrm{N}$} & \multirow[b]{2}{*}{ Years } & \multicolumn{9}{|c|}{ Month } \\
\hline & & & 3 & 4 & 5 & 6 & 7 & 8 & 9 & 10 & 11 \\
\hline Ødum, DK & 56.3 & 1961-95 & 2 & 14 & 53 & 73 & 74 & 68 & 43 & 16 & 2 \\
\hline Sola, N & 58.9 & $1957-91$ & 1 & 11 & 43 & 62 & 65 & 61 & 37 & 15 & 2 \\
\hline Ås, $\mathrm{N}$ & 59.7 & $1970-90$ & & 6 & 50 & 71 & 73 & 62 & 30 & & \\
\hline Helsinki, F & 60.3 & 1971-90 & & 4 & 47 & 70 & 76 & 62 & 28 & 5 & \\
\hline Bodø, N & 67.3 & $1957-92$ & & 2 & 22 & 46 & 51 & 45 & 19 & 3 & \\
\hline Apukka, F & 66.6 & $1970-90$ & & & 20 & 60 & 69 & 46 & 12 & 1 & \\
\hline Tromsø, N & 69.7 & $1951-91$ & & & 8 & 35 & 49 & 37 & 10 & 1 & \\
\hline Pasvik, N & 69.1 & 1957-91 & & & 8 & 41 & 52 & 38 & 9 & & \\
\hline
\end{tabular}

Ødum at $56^{\circ} \mathrm{N}$ as a reference site, Table 3 indicates that the yield potential of an irrigated crop might be about $85 \%, 60 \%$ and $44 \%$ of that at Ødum at about $60^{\circ} \mathrm{N}, 67^{\circ} \mathrm{N}$ and $70^{\circ} \mathrm{N}$, respectively. The difference between the coast and the interior at comparable latitudes seemed to be greatest at $67^{\circ} \mathrm{N}$, between Bodø and Rovaniemi (Apukka). After reduction for soil moisture deficit, the relative values of the accumulated GI at the same three latitudes along the coast of Norway became $101 \%, 69 \%$ and $52 \%$, respectively, whilst in Finland and up to Pasvik in Norway the accumulated GI was $79 \%, 61 \%$ and $49 \%$ of the Danish reference. The bulk of the big difference between west and east at about $60^{\circ} \mathrm{N}$ came between southeastern Norway and Helsinki, because Ås, at about the same longitude as Ødum, attained $94 \%$ of the reference sum. At $67^{\circ} \mathrm{N}$ the advantage of Rovaniemi over Bodø under irrigated conditions, RTI, turned into a disadvantage of similar magnitude under rainfed conditions, GI. In the far north, a similar, but much less pronounced, change appeared between coastal Troms $ø$ and inland Pasvik.

Table 2. Soil moisture deficit as long-term difference between the combined index of radiation and temperature (RTI) and the combined growth index (GI), both multiplied by 100, ((RTI-GI)100). Contributing indices only for days with diurnal mean temperature above $5^{\circ} \mathrm{C}$, after passing $5^{\circ} \mathrm{C}$ for a 7 -day period in spring and until passage of the same temperature in autumn.

\begin{tabular}{|c|c|c|c|c|c|c|c|c|}
\hline \multirow[b]{2}{*}{ Location } & \multirow[b]{2}{*}{${ }^{\circ} \mathrm{N}$} & \multirow[b]{2}{*}{ Years } & \multicolumn{6}{|c|}{ Month } \\
\hline & & & 5 & 6 & 7 & 8 & 9 & 10 \\
\hline Ødum, DK & 56.3 & 1961-95 & 12 & 30 & 34 & 36 & 9 & 1 \\
\hline Sola, N & 58.9 & 1957-91 & 9 & 20 & 20 & 13 & 2 & \\
\hline Ås, N & 59.7 & $1970-90$ & 11 & 27 & 25 & 17 & 3 & \\
\hline Helsinki, F & 60.3 & $1971-90$ & 13 & 40 & 36 & 18 & 3 & \\
\hline Bodø, $\mathrm{N}$ & 67.3 & 1957-92 & 2 & 12 & 8 & 6 & 1 & \\
\hline Apukka, F & 66.6 & $1970-90$ & 2 & 20 & 30 & 13 & 1 & \\
\hline Troms $\emptyset, \mathrm{N}$ & 69.7 & 1951-91 & & 4 & 9 & 5 & & \\
\hline Pasvik, N & 69.1 & 1957-91 & 1 & 7 & 16 & 8 & 1 & \\
\hline
\end{tabular}


Seminar in honour of the 100th anniversary of MTT

Table 3. Accumulated long-term annual indices over the growing season, defined as days between passage of a 7-day average of $5^{\circ} \mathrm{C}$ air temperature in spring and autumn, for a reference station at $56^{\circ} \mathrm{N}(\emptyset \mathrm{dum}$, Denmark), and at $60^{\circ} \mathrm{N}$ ( $\AA$ s, Norway). 'West' is the coast of Norway, and 'East' is Finland and Norway's Pasvik. RTI = combined radiation and temperature index. GI = combined radiation, temperature and soil moisture index.

\begin{tabular}{|c|c|c|c|c|c|c|}
\hline $\begin{array}{l}{ }^{\circ} \mathrm{N} \\
\text { approx. }\end{array}$ & West & $\begin{array}{c}\text { RTI } \\
\text { Ødum/Ås }\end{array}$ & East & West & $\underset{\text { GI }}{\text { GI } / \AA ̊ s}$ & East \\
\hline 56 & & 106 & & & 71 & \\
\hline 60 & 91 & 89 & 90 & 72 & 67 & 56 \\
\hline 67 & 57 & & 63 & 49 & & 43 \\
\hline 70 & 43 & & 45 & 37 & & 35 \\
\hline
\end{tabular}

Table 4. Number of cultivars of spring barley (Hordeum vulgare L.) and timothy (Phleum pratense L.) on national lists of recommended cultivars for 1997 in the Nordic countries, according to three types of origin: 'National' = bred in the country, 'Other Nordic' = bred in another Nordic country, 'Others' = bred in other countries.

\begin{tabular}{lrcccrcrr}
\hline Country & \multicolumn{2}{c}{$\begin{array}{c}\text { National } \\
\text { Barley Timothy }\end{array}$} & \multicolumn{2}{c}{$\begin{array}{c}\text { Other Nordic } \\
\text { Barley Timothy }\end{array}$} & $\begin{array}{c}\text { Others } \\
\text { Barley Timothy }\end{array}$ & \multicolumn{2}{c}{$\begin{array}{c}\text { Sum } \\
\text { Barley Timothy }\end{array}$} \\
\hline Denmark & 9 & 1 & 8 & 1 & 32 & 1 & 49 & 3 \\
Finland & 12 & 9 & 8 & 5 & 1 & 0 & 21 & 14 \\
Iceland & 0 & 2 & 8 & 3 & 0 & 0 & 8 & 5 \\
Norway & 5 & 4 & 4 & 1 & 1 & 0 & 10 & 5 \\
Sweden & 21 & 7 & 3 & 1 & 15 & 1 & 39 & 9 \\
\hline
\end{tabular}

The above assessments by climatic indices refer to a hypothetical crop that might be associated with a pasture with a relatively low leaf area index. The full interaction of weather with a variety of crops was not explored. The origin of cultivars on national recommended lists may be taken as an indication of the constraints on the choice of suitable plant material in the different Nordic countries (Helgadottir 1996, Meddelelser fra sortsafprøvningen 1997, Statens landbrukstilsyn 1997, Statens Växtsortsnämnd 1997, Växtsortsnämnden 1997). On the Danish list of spring barley cultivars, more than $60 \%$ were bred outside the Nordic countries, and on the Swedish list about $40 \%$; the other countries each had one or none in this category (Table 4). For perennial timothy, only one out of three cultivars originated from other European countries on the Danish list and one out of nine on the Swedish list. In the other three countries only national cultivars or those from other Nordic countries were officially recommended for use. If we assume that the official performance testing of cultivars is an objective way of screening suitable plant material, these statistics clearly show the need for locally adapted plant material in marginal crop production areas.

Assessment of production potential has to combine climatic parameters with soil data. Specific requirements of individual crops make crop growth models useful tools in expressing production potential in agronomically meaningful ways (SNP 1992). The climatic constraints on crop production will be properly expressed only when climatic information is combined with soil data, the specific requirements of individual crops and with the relevant management practices. Modern information technology offers great possibilities in analyses of crop production potential and its variation geographically as 
Vol. 7 (1998): 149-160.

well as in time. A wide range of applications can be indicated from land capability studies, administrative duties, strategic and tactical planning in agriculture and farm operational purposes to teaching.
Acknowledgements. The author is indebted to Mr Endre Skaar, Mr Jørgen E. Olesen and Dr Reijo Solantie for providing the weather data. The insightful comments on the manuscript from Dr Ole Hans Baadshaug are gratefully acknowledged.

\section{References}

Ángström, A., Liljequist, G.H. \& Wallén, C.C. 1974. Sveriges klimat. 3:e uppl. Generalstabens litografiske anstalts förlag. Stockholm. 188 p. Appendix.

Angus, J.F., Kornher, A. \& Torssell, B.W.R. 1980. A systems approach to estimation of Swedish ley production. Progress report 1979/80. Rapport 85. Institutionen för văxtodlingslăra, Sveriges lantbruksuniversitet. $29 \mathrm{p}$.

Baadshaug, O.H. 1974. Jordbruksmessig utnytting av fjelltraktene. En oversikt over norske undersøkelser. Forskning og forsøk i landbruket 25, 4. Supplementshefte. 53 p.

Bleken, M.A. \& Skjelvåg, A.O. 1986. The phenological development of oat (Avena sativa L.) cultivars as affected by temperature and photoperiod. Acta Agriculturæ Scandinavica 36: 353-365.

Bruun, I. 1967. Standard normals 1931-60 of the air temperature in Norway. Det norske meteorologiske institutt, Oslo. 270 p.

Eikeland, H.J. 1936. Forsøk med vårkveite, havre og bygg pá forsøksgarden Voll og pá $\mathbf{4 3}$ gardsfelt i Trøndelag og Møre og Romsdal i ára 1926-1936. Melding frá Statens forsøksgard Voll. Landbruksdirektørens ársmelding, tillegg $\mathrm{H}$ : 8-72.

Einarsson, M.A. 1972. Evaporation and potential evapotranspiration in Iceland. Vedurstofa Islands. Reykjavík. 27 p.

Eriksson, B. 1986. Nederbörds och humiditetsklimatet i Sverige under vegetationsperioden. SMHI Rapporter, Meteorologi och klimatologi (RMK) 46. 73 p.

Fagerberg, B. 1991. The effect of weather fluctuations on simulated ley growth in Sweden. Swedish Journal of Agricultural Research 21: 95-105.

Foss, S. 1968. Vekstrytme hos timoteisorter. Forskning for forsøk $i$ landbruket 19: 487-518.

Geisler, G. 1980. Pflanzenbau. Verlag Paul Parey, Berlin \& Hamburg. 480 p.

Gjessing, Y.T. 1969. Local climates and growth climate of the Sognefjord region, the radiation climates. Meteorologiske annaler 5: 395-428.

Hay, R.K.M. 1990. The influence of photoperiod on the dry matter production of grasses and cereals. Tansley Reviews No 26. New Phytologist 116: 233-254.

Heide O.M. 1980. Studies on flowering in Poa pratensis L. ecotypes and cultivars. Meldinger fra Norges landbrukshøgskole 59, 14. $27 \mathrm{p}$.

- 1985. Physiological aspects of climatic adaptation in plants with special reference to high-latitude environments. In: Kaurin, A. et al. (eds.). Plant growth in the North. Norwegian University Press, Oslo. p. 122.

- 1994. Control of flowering and reproduction in temperate grasses. New Phytologist 128: 347-362.

- , Hay, R.K.M. \& Baugerød, H. 1985. Specific daylength effects on leaf growth and dry matter production in high-latitude grasses. Annals of Botany 55: 579-586.

Heldal, B. 1969. Evaporation from different evaporation pans in relation to meteorological conditions. Meldinger fra Norges landbrukshøgskole 48, 25. $42 \mathrm{p}$.

Helgadottir, A. (ed.) 1996. Nytjuplöntur á Islandi 1997. Rannsóknastofnun landbúnadarins. $15 \mathrm{p}$.

Hutchinson, M.F., Nix, H.A. \& McMahon, J.P. 1992. Climate constraints on cropping systems. In: Pearson, C.J. (ed.). Field Crop Ecosystems. p. 37-58. (Vol. 18 of Goodall, D.W. (ed.). Ecosystems of the World). Johannessen, T.W. 1970. The climate of Scandinavia. In: Wallén, C.C. Climates of Northern and Western Europe. World Survey of Climatology. Volume 5. p. 2380.

Kvifte, G., Hegg, K. \& Hansen, V. 1983. Spectral distribution of solar radiation in the Nordic countries. Journal of Climate and Applied Meteorology 22: 143-152.

Madsen, H.B., Holst, K.A. \& Mikkelsen, S.A. 1987. The use of EC-soil map in modelling and mapping the root zone capacity and irrigation need. A case study from Denmark. EC-Workshop on computerization of land use data for agricultural and environmental planning, 20-22 May 1987, Pisa, Italy. 14 p.

Meddelelser fra sortsafprøvningen 1997. Officiel sortsliste. Meddelelser fra sortsafprovningen 16. Særnummer april 1997. $73 \mathrm{p}$.

Mikkelsen, H.E. \& Olesen, J.E. 1991. Sammenligning af metoder til bestemmelsen af potentiel vandfordampning. Tidsskrift for Planteavls Specialserie. Beretning nr. S 2157-1991. 67 p.

Mikkelsen, S.A. \& Olesen, J.E. 1984. Computer-aided mapping of growing degree days for Denmark, calculated from monthly temperature normals. Acta Agriculturce Scandinavica 34: 330-338.

Mischenko, Z.A. 1984. Agroclimatic mapping of the continents. CAgM Report No 23. World Meteorological Organization, Agricultural Meteorology. 109 p.

Mukula, J. \& Rantanen, O. 1987. Climatic risks to the yield and quality of field crops in Finland. I. Basic facts about Finnish field crops production. Annales Agriculturae Fenniae 26: 1-18.

NU B 1977. Naturgeografisk regionindelning av Norden. 


\title{
AGRICULTURAL AND FOOD SCIENCE IN FINLAND
}

\section{Seminar in honour of the 100th anniversary of MTT}

NU B 1977:32. Nordisk Ministerrád, Stockholm. 7:32.

Olesen, J.E. \& Mikkelsen, S.A. 1985a. A meteorological model for calculating the moisture content of ripe spring barley. Part I. Model description. Acta Agriculturœe Scandinavica 35: 361-368.

- \& Mikkelsen, S.A. 1985b. A meteorological model for calculating the moisture content of ripe spring barley. Part II. Model results. Acta Agriculturœ Scandinavica 35: 369-374.

Penman, H.L. 1956. Evaporation: an introductory survey. Netherlands Journal of Agricultural Science 4: 9-29.

Rantanen, O. \& Solantie, R. 1987. Climatic risks to the yield and quality of field crops in Finland. II. Cultivation zones and sub-divisions. Annales Agriculturae Fenniae 26: 19-37.

Ritchie, J.T. 1972. Model for predicting evaporation from a row crop with incomplete cover. Water Resources Reserach 8: 1204-1213.

Skjelvåg, A.O. 1981a. Experimental and statistical methods of plant experiments used in an agroclimatic investigation in Aust-Agder, Norway. Acta Agriculturæ Scandinavica 31: 343-357.

- $1981 \mathrm{~b}$. Effects of climatic factors on the growth and development of the field bean (Vicia Faba L. var. minor) II. Phenological development in outdoor experiments. Acta Agriculturæ Scandinavica 31: 372281.

- 1986a. Temperatur og fenologisk utvikling hos eittárig raigras. Forskning og forsøk $i$ landbruket 37: 219-224.

- 1986b. Utrekning av første sádag ved vêrobservasjonar. Forskning og forsøk i landbruket 37: 295-301.

- $1986 \mathrm{c}$. Fenologisk utvikling hos eittárig raigras i AustAgder. Forskning og forsøk i landbruket 37: 303-311.

- 1987. Første berrmarksdag om váren i Aust-Agder. Norsk landbruksforsking 1: 215-223.
SNP 1992. Agroklimatisk kartlegging av Norden. Skrifter och rapporter $\mathrm{nr}$. 5. Samnordisk planteforedling. $97 \mathrm{p}$.

Solantie, R. 1975. Haihdunnasta Suomessa. In: Yliniemi, J. (ed.). Geofysiikan päivät, Oulu 26.-27.5.1975. p. 195-202.

- 1976. Jărvien vaikutus lämpötilan mesoskaala-analyysiin Suomessa. IImatieteen Laitoksen Tiedonantoja $30.72 \mathrm{p}$.

- 1987. The difference between precipitation and evaporation on cultivated areas from the disappearance of snow to the end of July 1931-1960. In: Atlas of Finland, folio 131 (Climate) 19n. National Board of Survey \& Geographical Society of Finland.

Sømme, A. (ed.) 1968. A Geography of Norden. J.W. Cappelens Forlag, Oslo. 343 p. Appendix

Statens landbrukstilsyn 1997. Offisiell sortsliste 1997/98. $20 \mathrm{p}$.

Statens Växtsortsnämnd 1997. Sortslista 1997. Meddelanden från Statens Växtsortsnämnd 2/1997. 20 p.

Strand, E. 1964. Dyrkingssoner for jordbruksvekster i Norge. Meldinger fra Norges landbrukshøgskole 43, 9. $16 \mathrm{p}$.

- 1989. Resultater fra jord-og plantekulturforskningen, korn. In: Den gronne evolusjon. Landbruksforlaget, Oslo. p. 144-154.

Torssell, B.W.R. \& Kornher, A. 1983. Validation of a yield prediction model for temporary grasslands. Swedish Journal of Agricultural Research 13: 125-135.

Utaaker, K. 1979. Lokal- og vekstklima i Sogn. Forskning og forsek i landbruket 30: 113-204.

Växtsortsnämnden 1997. Meddelanden frán Växtsortsnämnden 3/1997. $23 \mathrm{p}$.

Vinterherdighet 1988 . Vinterherdighet i nordisk vekstforedling. Nordisk Ministerrád (Nord. 1988:84). SNP-publikation 19. 48 p. Appendix.

\section{SELOSTUS}

\section{Kasvintuotannon ilmasto-olosuhteet Pohjoismaissa}

\author{
Arne Oddvar Skjelvåg \\ Agricultural University of Norway, Norja
}

Ilmasto vaikuttaa nykyään satoon oleellisesti. Sen sijaan ennen maaperän viljavuus rajoitti satoa ilmastoa enemmän. Pohjoismaissa säteily vaihtelee alueellisesti vähemmän kuin lämpötila kasvukauden aikana. Kasvukauden aikana mitatuista säteilystä ja lämpötilasta voidaan laskea kasvin kasvua kuvaava kumuloituva indeksiluku. Tämä vuotuinen kasvuindeksi saa 56. pohjoisella leveysasteella (Ødum, LänsiJyllanti) arvon 106 ja pienenee arvoihin 90,60 ja 44 siirryttäessä pohjoiseen $60 ., 67$. ja 70. leveysasteille. Norjan rannikolla ja Suomen sisämaassa 67. leveys- asteella mitattujen kasvuindeksien ero oli hyvin pieni tai vain noin $10 \%$ Suomen sisämaan eduksi. Kun kasvuindeksiä laskettaessa otettiin huomioon myös kuvitteellisen hietamaalla viljellyn laitumen kosteusolot, saatiin säteilyä, lämpötilaa ja kosteusoloja kuvaavan kasvuindeksin summaksi Ødumissa 71 . Norjan rannikolla 60., 67. ja 70. leveysasteilla lasketut arvot olivat 72,49 ja 37, kun taas Suomessa vastaavilla leveysasteilla indeksit olivat 56,43 ja 35 . Kasvintuotannon potentiaalia voitaneen suoraan arvioida kumuloidun kasvuindeksin avulla. 